\title{
Properties of new-generation hybrid layers combining hardfacing and nitriding dedicated to improvement in forging tools' durability
}

\author{
Marcin Kaszuba ${ }^{1} \cdot$ Paweł Widomski $^{1}$ (1) $\cdot$ Piotr Białucki ${ }^{1} \cdot$ Artur Lange $^{1} \cdot$ Bożena Boryczko $^{2} \cdot$ Mariusz Walczak $^{3}$
}

Received: 4 April 2020 / Revised: 23 April 2020 / Accepted: 6 June 2020 / Published online: 22 June 2020

(C) The Author(s) 2020

\begin{abstract}
This article deals with the subject of layers produced in a hybrid process combining hardfacing and nitriding. These layers are characterized by improved resistance to wear, which arises from the synergy between favorable materials during hardfacing and nitriding treatment. Tests were conducted on hot-work tool steel (H11) samples. Hardfaced layers consisting of three layers were applied to these samples, where layers were made from two materials—Robotool 46 and Hardface VMolc powder wires. Next, samples of both materials were nitrided using ZeroFlow gas nitriding technology, with control of potential aimed at obtaining a diffusion layer without a white zone of nitrides on the surface. The next step was to investigate the properties of hardfaced layers and of layers hardfaced after nitriding treatment. Conducted tests covered observations of the microstructure, microhardness measurements as a function of distance from the surface, measurement of stresses in the surface layer by means of X-ray diffraction, and tribological tests. Obtained test results show that hybrid layers combining hardfacing and nitriding may be suitable for improving the lifetime of tools applied in hot forging processes.
\end{abstract}

Keywords Nitriding $\cdot$ Hardfacing $\cdot$ Forging tools $\cdot$ Durability $\cdot$ Wear $\cdot$ Hybrid layer

\section{Introduction}

The lifetime of tools in forging process has been a subject of research by many scientific centers for a long time. This research concerns, among other things, wear mechanisms causing destruction of the surface and surface layer of tools as well as methods of increasing wear resistance. In recent years, there has been a distinct rise of interest in this subject matter [1-3].

The main reason for low durability of tools used in industrial forging processes is that working conditions are extremely heavy. Over the course of operation, these tools

Paweł Widomski

pawel.widomski@pwr.edu.pl

1 Department of Metal Forming, Welding and Metrology, Wroclaw University of Science and Technology,

Lukasiewicza Street 5, Wrocław, Poland

2 Department of Metal Working and Physical Metallurgy of Non-Ferrous Metals, AGH University of Science and Technology, Al. Mickiewicza 30, 30-059 Kraków, Poland

3 Department of Materials Engineering, Faculty of Mechanical Engineering, Lublin University of Technology, Nadbystrzycka 36 Street, 20-618 Lublin, Poland are constantly exposed to the action of destructive factors such as intense thermal fatigue, periodically variable mechanical loads, and intense friction under high pressures. The tool's surface layer is particularly exposed to the action of these factors, which is why the majority of destructive mechanisms that occur pertain to this area of the tool. Therefore, modifying the surface layer properties of forging tools is the most effective way to improve their durability $[4,5]$.

In recent years, growing interest in new methods of improving the durability of forging tools has been observed. As scanning electron microscopy, atomic force microscopy, and various methods of detecting chemical and phase composition advanced and became more available, many new chemical compounds for coatings and layers were discovered. New materials characterized by superior functional properties have enormous potential for application in many engineering disciplines. In recent years, many new solutions have also been developed in the field of methods improving the lifetime of forging tools. Among these solutions, hybrid layers are dominant, i.e., those combining various surface treatment methods for the purpose of obtaining new properties and higher wear resistance. Hybrid layers combining nitriding with PVD coatings [6], nitriding with CVD coatings [7], shot peening with nitriding [8], and various types 
and kinds of coatings on a single tool [9] are known. A new solution, characterized by high potential and broad capabilities, is the combination of popularly applied hardfacing with thermochemical nitriding treatment [10]. This paper provides detailed test results of hybrid layers combining hardfacing with nitriding treatment, the structure, properties, and wear resistance of which were tested under laboratory conditions.

As is known, nitriding increases tools' resistance to abrasion and fatigue strength and improves corrosion resistance [11]. Observations of many industrial forging processes, in which nitrided tools were applied, have proven that this treatment makes it possible to increase tool lifetime several times over [12]. Conducted tests demonstrated that nitrided layers with a uniform and specific structure can effectively improve tool lifetime. Despite the fact that nitriding technology has been mastered quite well and applied for many years, it is increasingly unable to meet expectations regarding the durability of tools used in advanced, high-performance hot die forging processes [13].

In recent years, the durability-improving technology based on modification of the surface layer, that is being used with increasing frequency, is hardfacing, particularly preventive hardfacing $[14,15]$. It is based on coating forging tools with a layer of metal by using the hardfacing (padding) technique with simultaneous melting of the substrate, where it is important to precisely melt the hardfacing product (padding weld) with substrate material, whose share in the hardfacing metal may reach up to $60 \%$. The hardface layer is tasked with ensuring the best possible operational properties of the surface layer, acting preventively (enrichment), or in the case of regenerative hardfacing, restoring these properties through surface reconstruction [16]. Hardfacing performed in forges is currently most often performed, depending on the plant, by means of available welding methods, including gas tungsten arc welding (GTAW), gas metal arc welding (GMAW), self-shielded flux-cored arc welding (FCAW-S) or laser surface melting (LSM) [17]. Observations of hardfaced forging tools conducted until now have demonstrated that their durability can effectively be improved in this manner [18-20].

The authors' most recent studies concerned the simultaneous application of hardfacing combined with later nitriding. Preliminary results showed nearly twofold improvement in durability in comparison with standard tools, on which only one of the aforementioned techniques was applied [10].

There is little information in the available literature concerning the possibility of applying hybrid surface layers, created by combining hardfacing with nitriding, in order to improve the durability of forging tools. However, there are studies relating to nitriding of padding welds, welded machine parts, hardfaced combustion engine valves, or even purposeful hardfacing and nitriding of elements of steel structures $[21,22]$. These studies indicate elevated corrosion resistance, tribological resistance, and higher mechanical strength of such layers.

Due to the observed enormous potential of layers of this type, activities were undertaken to explain the causes of their superior wear resistance. According to one definition of durability, the durability of a tool can be defined as its capacity to withstand individual destructive mechanisms occurring in a given process. One of the primary destructive mechanisms occurring in hot die forging processes is abrasive wear, which is why special attention has been devoted in this paper to investigating the resistance of obtained hybrid layers to abrasive wear. The mechanical and structural properties of layers responsible for their wear resistance were also analyzed.

\section{Applied materials and testing methods}

Tests were conducted on samples that were prepared so as to be representative with respect to the process of manufacturing forging tools. The base part of every sample was a block with dimensions of $100 \times 100 \times 50 \mathrm{~mm}$ made of $\mathrm{H} 11$ steel, heat-treated by quenching and high-temperature tempering to a hardness of approx. 450-500 HV0.1, which corresponds to typical heat treatment of forging tools applied in hot die forging processes. On this substrate, three hardfaced layers were applied by self-shielded flux-cored arc welding (FCAW-S). Two powder wires manufactured by welding alloys-Robotool 46G and Hardface VMolc, the chemical compositions of which are presented in Table 1-were applied as the padding weld material. Robotool $46 \mathrm{G}$ wire is popularly used as weld metal for hardfacing of dies for forging on presses, while Hardface VMolc wire has been

Table 1 Chemical composition and properties of materials applied in hardfacing process

\begin{tabular}{|c|c|c|c|c|c|c|c|c|c|c|c|}
\hline \multirow[t]{2}{*}{ Material } & \multicolumn{9}{|c|}{ Element content as $\%$} & \multirow[t]{2}{*}{ Est. hardness [HRC] } & \multirow[t]{2}{*}{ Source } \\
\hline & $\mathrm{C}$ & $\mathrm{Mn}$ & $\mathrm{Si}$ & $\mathrm{Cr}$ & Mo & $\mathrm{Ti}$ & $\mathrm{Ni}$ & $\mathrm{V}$ & $\mathrm{Fe}$ & & \\
\hline H11 steel & 0.38 & 0.92 & 0.30 & 4.85 & 1.30 & 0.02 & 0.34 & 0.28 & Rem. & - & According to chem. analysis \\
\hline Robotool 46G & 0.20 & 0.90 & 0.50 & 5.10 & 3.80 & 0.25 & - & - & Rem. & $44 \mathrm{HRC}$ & Welding alloys catalog \\
\hline Hardface VMolc & 0.08 & 1 & 0.6 & 10 & 2.5 & - & 1.8 & - & Rem. & 34-36 HRC & Welding alloys catalog \\
\hline
\end{tabular}


proposed as a material for regeneration of dies for hammer forging.

After hardfacing, samples were mechanically processed by grinding in order to obtain a uniform, smooth surface. In mechanical processing, only unevennesses were removed, so that the analyzed surface was completely made of the material making up the third layer of the padding weld. According to the adopted technology, approx. $90 \%$ of this third layer should consist of the powder wire weld metal. Figure 1 shows a view of the hardfaced sample after mechanical processing.

Ground, hardfaced samples were divided into two parts for the purpose of subjecting one of them to the ZeroFlow gas nitriding process with low potential, so as to obtain a diffusion layer without a zone of continuous nitrides on the surface. This processing variant is dedicated for application on forging tools, as confirmed in other studies [23]. The nitriding process was conducted at $550^{\circ} \mathrm{C}$ over approx. $13 \mathrm{~h}$.

Next, laboratory tests of the obtained surface layers were conducted, covering:

- examinations of the microstructure, done using a Keyence VHX-6000 digital microscope with magnification up to $1000 \times$, with the capability of measurement under a variable lighting angle, depth of field composition in 2D and 3D, HDR plus technology, in which photographs of the microstructure were taken. The microstructure in the padding weld, heat-affected zone, and native material was observed;

- microhardness measurements of the surface layer, which were performed on a LECO LM-100AT microhardness tester by the Vickers method under $0.98 \mathrm{~N}$ load. Measurement was performed on the cross section, at points distributed along the vector running perpendicularly from the surface into the material;

- laboratory tests included measurement of stresses in the surface layer by X-ray diffraction, on the surface, and at depths of 50,100, and $150 \mu \mathrm{m}$. For the purpose of

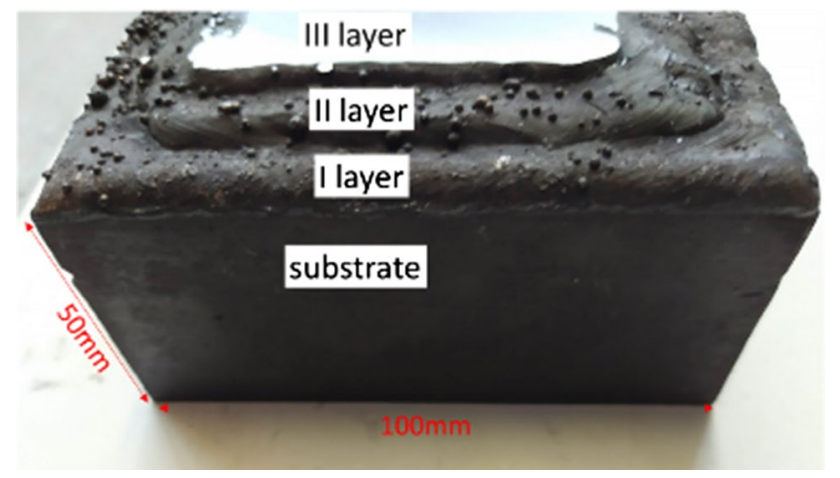

Fig. 1 View of sample hardfaced with Hardface VMolc wire after mechanical processing measuring stresses at the indicated depths, the surface was etched electrolytically, with removal of a $50 \mu \mathrm{m}$ $( \pm 10 \mu \mathrm{m})$ layer of thickness in every instance. Measurement was performed in two directions: $\mathrm{X}$ and $\mathrm{Y}$, after which mean stress was calculated in a flat stress/strain state. Tests were conducted at the Laboratory of Metallurgical Science and Chemical Analyses of the Institute of Non-Ferrous Metals in Skawina, accredited by the Polish Centre for Accreditation (PCA accreditation certificate no. 394). Tests were conducted on a Proto XRD residual stress systems machine.

- abrasive wear tests, conducted on sample surfaces. Wear tests were performed on a "ball-on-disk" tribotester from CSM Instruments under technically dry friction conditions at room temperature $22{ }^{\circ} \mathrm{C}$. Tungsten carbide balls with a diameter of $6 \mathrm{~mm}$ (calibrated by CSM Instruments) were used as the ball (i.e., countersample). Tests were conducted under $10 \mathrm{~N}$ load, with a linear speed of $10 \mathrm{~cm} / \mathrm{s}$, over a radius of $3 \mathrm{~mm}$. The total test path amounted to $250 \mathrm{~m}$, over which change of the friction coefficient was registered. The adopted measure of wear was volumetric loss of the sample, generated as the wear trace resulting from friction between the sample and countersample. For this purpose, the area of the sample's wear profile was measured along its circumference by means of a Dektak 150 contact profilometer from Veeco Instruments. The measuring needle's radius of curvature was $2 \mu \mathrm{m}$, under $3 \mathrm{mg}$ needle load. Volumetric loss was determined as the product of the mean value of the sample's wear area (sample loss) and the circumference of the circular wear trace formed in the ball-on-disk test. In addition, the so-called wear factor $K$ was determined as a comparative measure of wear. Next, obtained surface areas of wear tracks on the tested samples were observed under a Tescan Vega III scanning electron microscope in order to determine the nature of wear. Observations of the worn surface and cross section were carried out.

\section{Results}

Tests were conducted under laboratory conditions in the sequence described in Sect. 2. Microstructure, properties, and resistance to wear were analyzed for the purpose of determining the influence of nitriding on the quality and strength of padding welds.

\subsection{Analysis of hybrid layers' microstructure}

Samples were prepared by cutting, grinding, and polishing, as well as etching with the following reagents: Nital 5\% and Vilella's. The image was analyzed throughout the entire cross section, with attention paid to the microstructure of 
individual areas and to transitional zones. Figure 2 presents photographs of the microstructure of the layer hardfaced with Robotool 46G material.

The padding weld made of three layers of Robotool 46 material on the substrate of $\mathrm{H} 11$ steel is visible in Fig. 2. The middle part shows a composite of the sample's entire surface (made from photographs taken at $200 \times$ magnification in the 3D HDR system), from the surface layer down to the native material (NM). The left side shows characteristic fusion sites between individual padding weld layers, between the padding weld and the substrate material, and the transition of the HAZ into NM (mag. 200×). On the right side, structures of individual padding weld layers, the HAZ and NM, are shown (mag. 500×). After hardfacing, the surfaces of the final padding weld layer were processed by grinding. Through observations of the hardfaced sample under a light microscope, it can generally be stated that the quality of individual layers is high, and no welding defects were observed. Individual passes of the padding weld are well visible in the cellular-dendritic structure, and a rather wide $H A Z$ can be seen in the native material.

A fine-grained structure of martensite from steel tempering is present in the structure of the native material (NM), with the presence of a small amount of residual austenite. The structure of $\mathrm{H} 11$ steel is characterized by banding, in which characteristic dark bands alternating with light bands are carbide precipitations. A wide HAZ, in which the steel's structure clearly changed, is visible in the upper part of the sample. Grains were refined, and banding was reduced. The structure of this area of the steel has the nature of tempering sorbite. The depth of fusion of the first layer is approx. $1 \mathrm{~mm}$, and the structure of the layer near the fusion line displays non-uniformity, in the form of tongues of the steel's material in the layer, resulting from movement of the bath in the weld pool. Such a structure forms in the case of a difference in chemical composition between the welding metal and substrate. In the case of intensive movement of the bath in the weld pool, a certain amount of the hardfaced material is introduced onto the surface of the padding weld.

A coarse-grained bainitic-martensitic structure, with a variable width of up to approx. $1 \mathrm{~mm}$, is present just under the fusion line. The structures of individual layers are similar and have a cellular-dendritic structure consisting of a fine-grained, low-tempered bainitic structure, with a large amount of carbides present on grain boundaries (most likely chromium carbides), and a certain amount of carbides present inside grains. A small amount of residual austenite is also visible.

In the area of fusion between individual layers, grains were refined, and there was an increased number of carbides
Fig. 2 Microstructure of layer hardfaced with three layers of Robotool 46G material

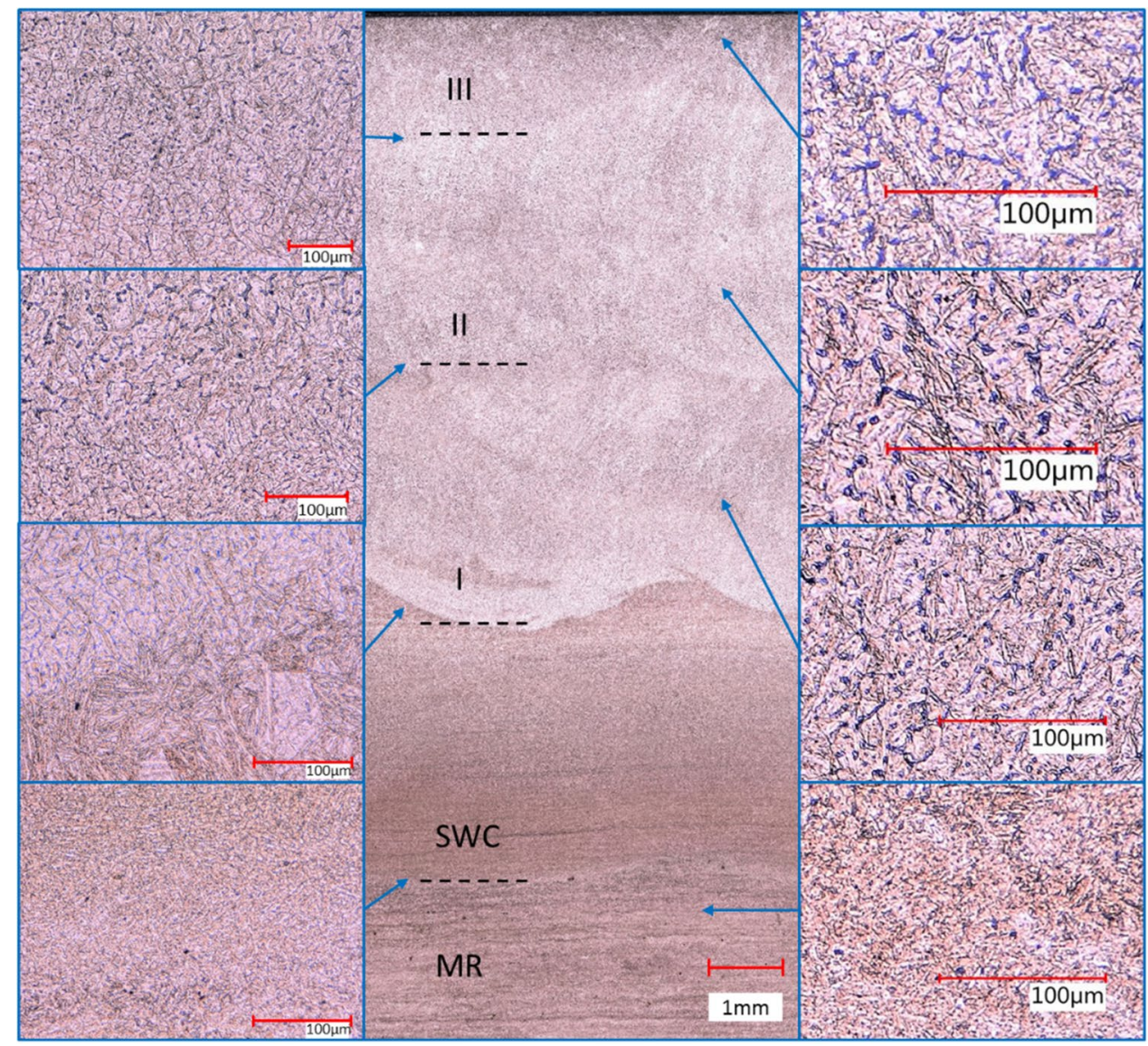


in the structure due to the influence of heat supplied during application of the next layer. The final layer of the padding weld, particularly the surface part, consists of low-tempered martensite.

The change of orientation of the crystallization axis of column grains in individual layers, visible throughout the entire padding weld, indicates correct performance of the hardfacing process, during which successive passes ran in different directions, thus refining the structure and preventing trans-crystallization.

Figure 3 shows a padding weld made of three layers of Robotool 46 material on the substrate of H11 steel, subjected to the ZeroFlow nitriding process at $550{ }^{\circ} \mathrm{C}$ for $13 \mathrm{~h}$. The middle part shows a composite of the sample's entire surface (made from photographs taken at $200 \times$ magnification in the 3D HDR system), from the surface layer down to the native material (NM). The left side shows characteristic fusion sites between individual padding weld layers, between the padding weld and the substrate material, and the transition of the HAZ into NM (mag. 200×). On the right side, structures of individual padding weld layers, the HAZ and NM, are shown (mag. 500×). After hardfacing, the surfaces of the final padding weld layer were processed by grinding. Through observations of the hardfaced sample under a light microscope, it can generally be stated that the quality of individual layers is high, and no welding defects were observed. Individual passes of the padding weld and a rather wide HAZ are well visible. A fine-grained structure of hightempered sorbite, with the presence of a very small amount of residual austenite, is present in the structure of the native material (NM). The structure of H11 steel lost its banding as a result of nitriding heat treatment. A wide HAZ is visible in the upper part of the sample. Grains were refined, and banding was reduced. The structure of this area of the steel has the nature of tempering sorbite. The structure between individual layers shows changes on the fusion boundary due to heat supplied as a result of application of the next layer, with an elevated amount of carbides in the structure. The structure itself of individual layers is similar, consisting of a fine-grained, high-tempered bainitic structure, with a large amount, larger than in the case of the sample that was not nitrided, of carbides present on grain boundaries (most likely chromium carbides), and a certain amount of carbides present inside grains. A small amount of residual austenite is visible on grain boundaries. A characteristic area is present on the fusion line between the second and third layers and is characterized by a thin lining of carbides along nearly the entire boundary of grains. The final padding weld layer,
Fig. 3 Microstructure of layer hardfaced with three layers of Robotool 46 material after nitriding treatment

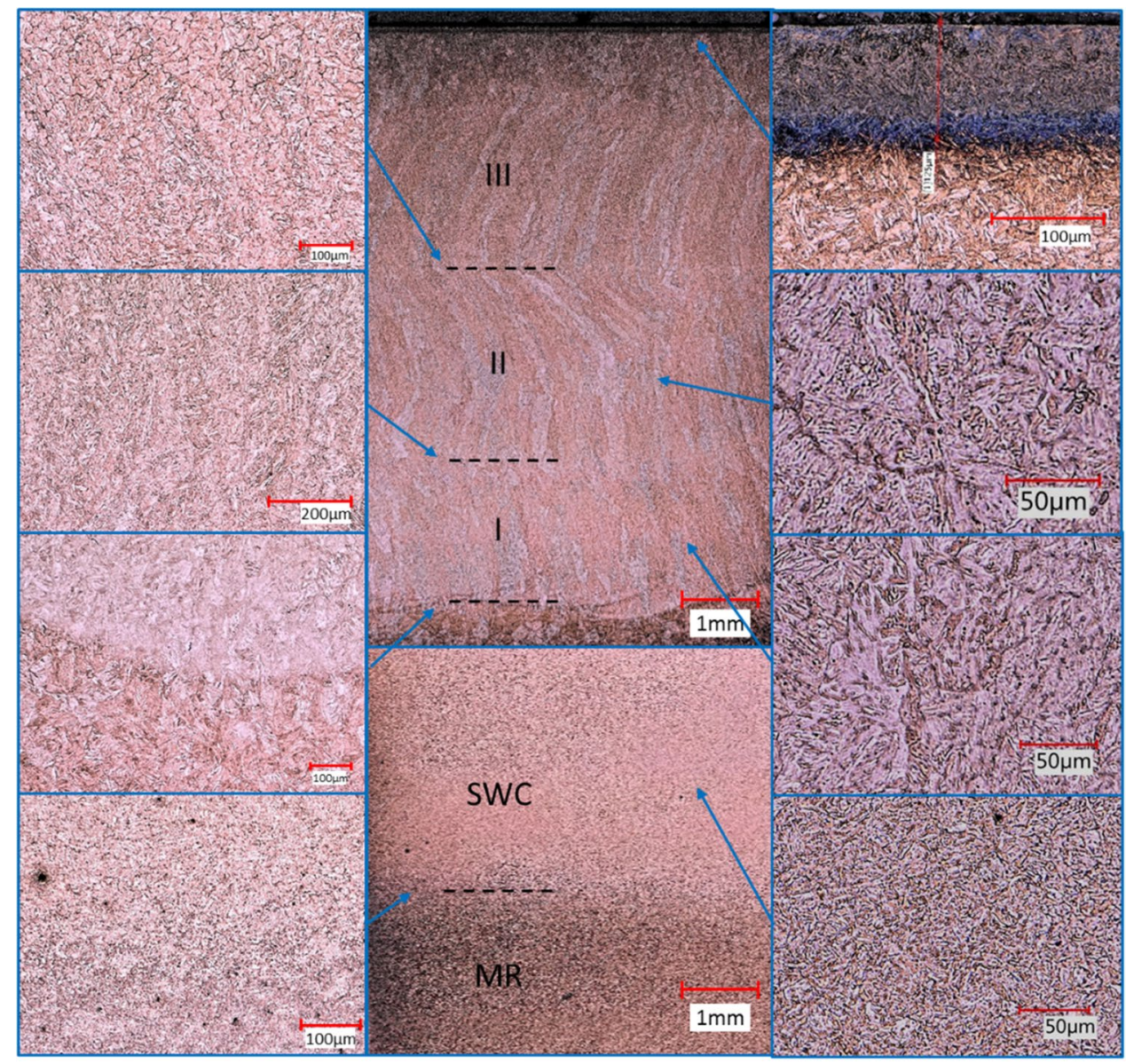


particularly the surface part, shows a nitrided layer with a mean depth of $140 \mu \mathrm{m}$, the hardness of which increased from 570 HV0.1 to above 1100 HV0.1.

The padding weld made of three layers of Hardface VMolc material on the substrate of $\mathrm{H} 11$ steel is visible in Fig. 4. The middle part shows a composite of the sample's entire surface (made from photographs taken at 200× magnification in the 3D HDR system), from the surface layer down to the native material (NM). The left side shows characteristic sites of mutual fusion between individual padding weld layers, fusion between the first padding weld layer and the substrate material, and the transition of the HAZ into NM (mag. 200x). On the right side, structures of individual padding weld layers, the HAZ and NM, are shown (mag. 500×). Through observations of the hardfaced sample under a light microscope, it can generally be stated that the quality of individual layers is high, and no welding defects were observed. Individual passes of the padding weld are well visible in the cellular-dendritic structure, and a rather wide HAZ can be seen in the native material. A fine-grained structure of martensite from steel tempering, similar in composition with the structure presented in Fig. 2, is present in the native material (NM). A wide HAZ, in which the steel's structure clearly changed, is visible in the upper part of the sample.
Grains were refined, and banding was reduced. The structure of this area of the steel has the nature of tempering sorbite. The depth of fusion of the first layer is approx. $1 \mathrm{~mm}$, and the structure of the layer near the fusion line shows a decarburization zone. Such a structure occurs in the case of a difference between the chemical composition of the welding metal and substrate material, particularly when there is a high difference in $\mathrm{Cr}$ and $\mathrm{C}$ content under the influence of heat supplied during application of the next layer. This causes the formation of an area where pure alloyed ferrite is present, and this can also be a cause of increased brittleness due to reactive diffusion and an increased tendency for hot fracture [24]. The structures of individual layers are similar and are cellular-dendritic, consisting of alloyed ferrite with bainite, where a more coarse-grained structure is present in the exterior layer compared to previous layers. In padding weld layers, there are no distinct carbide precipitations on grain boundaries, as can be seen in padding welds made of Robotool 46 wire (Figs. 2, 3); however, very fine carbide precipitations are present inside dendritic grains of the ferritic-bainitic structure. The structure of tempered martensite is present near the fusion line from the side of the HAZ.

Figure 5 presents photographs of the microstructure of the layer hardfaced with Hardface VMolc material after
Fig. 4 Microstructure of layer hardfaced with three layers of Hardface VMolc material

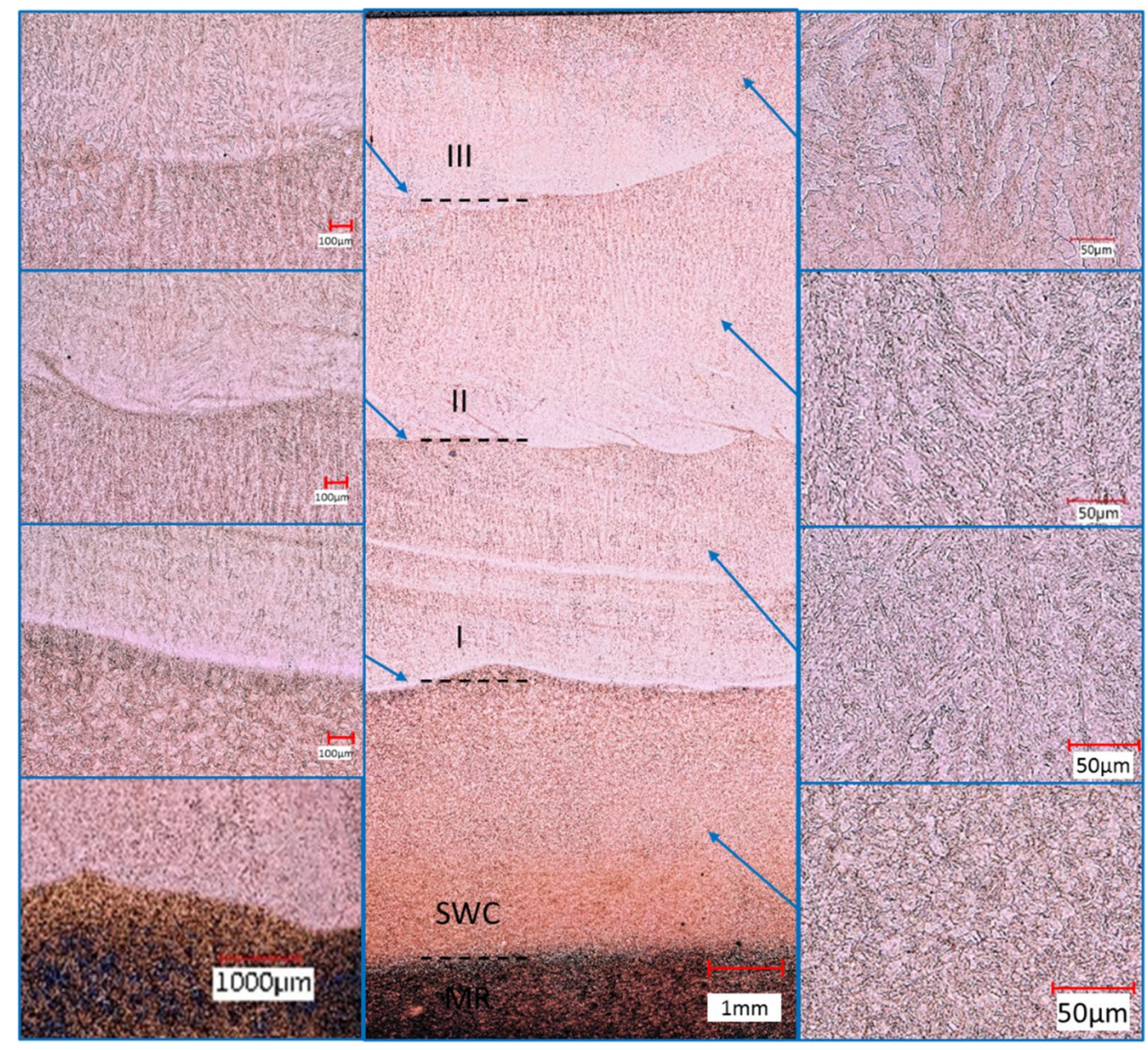


Fig. 5 Microstructure of layer hardfaced with three layers of Hardface VMolc material after nitriding treatment

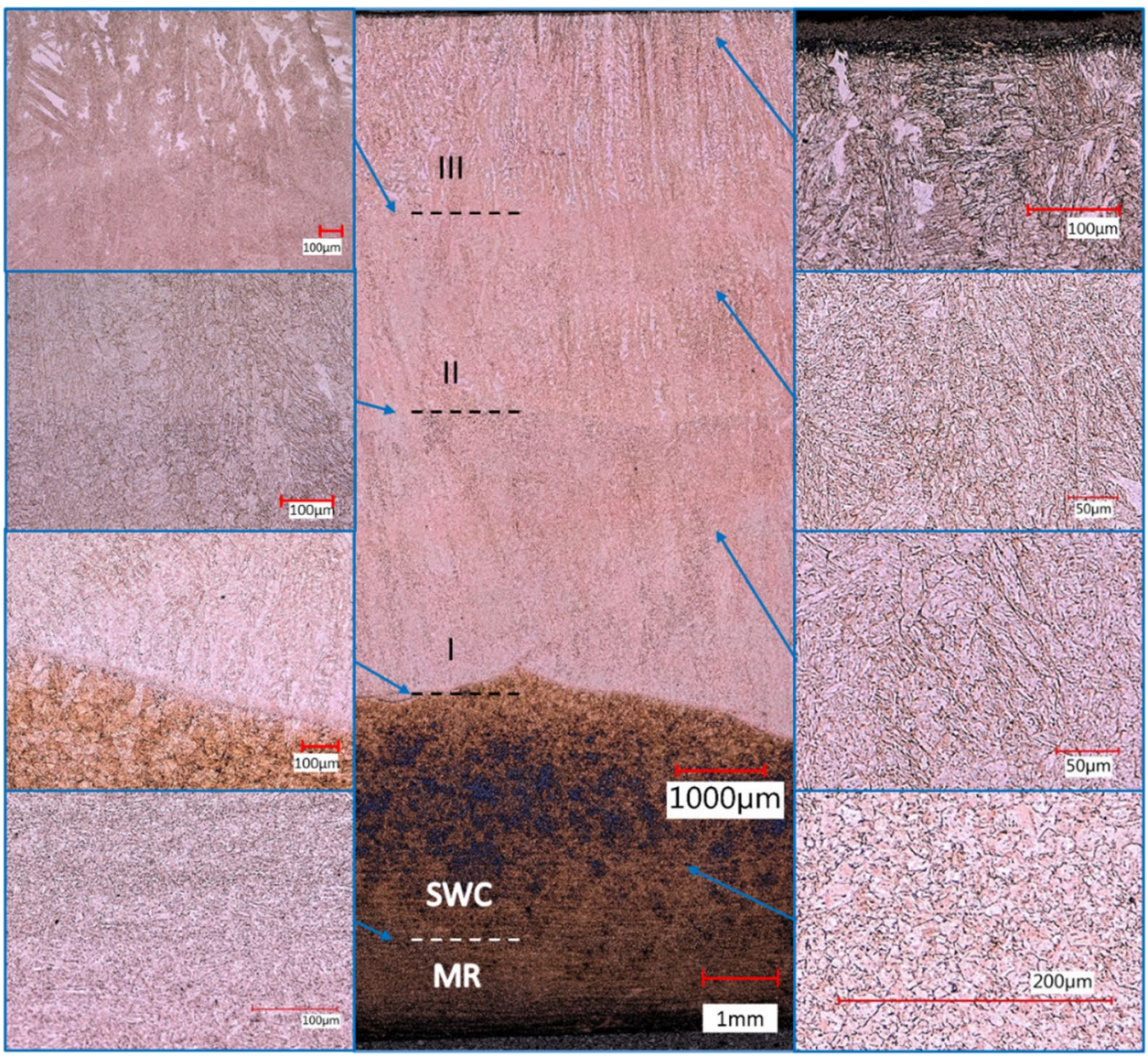

nitriding treatment. A thin nitrided layer, with a thickness of approx. $50 \mu \mathrm{m}$, is present on the surface of the padding weld. The structure of individual areas of the padding weld and of steel is similar to the structure prior to nitriding, with the exception of a greater number of fine carbide precipitations inside grains of the padding weld and in the HAZ.

\subsection{Microhardness measurement results}

The mechanical properties of the hybrid layers obtained on samples were analyzed in detail. The goal of tests was, among other things, to evaluate hardness on the cross section, particularly in the surface layer, the properties of which are of critical significance to processes accompanied by wear. For this purpose, microhardness was measured at a distance ranging from 0.01 to $7 \mathrm{~mm}$, with three measurements taken for each sample. The chart below presents microhardness as a function of distance from surface on a logarithmic scale, which was adopted in order to highlight the hardness of the nitrided layer within the $0.01-0.1 \mathrm{~mm}$ range, while simultaneously indicating hardness fluctuations throughout the entire cross section of the padding weld and heat-affected zone (Fig. 6).

First of all, the results presented above show the effect of hardfacing of samples with Robotool 46 and Hardface
VMolc materials. Robotool 46 powder wire made it possible to obtain a nearly uniform padding weld with a hardness of approx. $550 \mathrm{HV}$ near the surface and 550-600 HV at a depth up to $7 \mathrm{~mm}$. Local hardness reductions at a depth of approx. $0.1 \mathrm{~mm}$ and $3-5 \mathrm{~mm}$, shown in the chart, reflect transitional zones between successive layers, which was also confirmed in examinations of the microstructure. Similarly, the padding weld based on Hardface VMolc wire is characterized by hardness at a level of $400 \mathrm{HV}$, with local decreases at a depth of approx. $0.1 \mathrm{~mm}$ and $1 \mathrm{~mm}$, corresponding to fusion zones on the boundary between individual layers.

Selected materials can be used for hardfacing or rebuilding surface welding. Robotool $46 \mathrm{G}$ can be used as hardfacing for forging dies on presses, which are usually made of H11/X37CrMoV5-1 steel with a hardness of approx. 500 HV. Similarly, Hardface VMolc can hardface dies made of L6/55NiCrMoV7 steel, which is commonly used to produce dies for forging on hammers. The hardness of the steel matrix is usually around $380 \mathrm{HV}$.

The results of hardness measurement also made it possible to evaluate the profile and depth of formed nitrided layers. In the case of the padding weld based on Robotool 46 wire, a layer with increased hardness was revealed, reaching $1150 \mathrm{HV}$ near the surface and characterized by an effective thickness of approx. $140 \mu \mathrm{m}$ (according to the 
Fig. 6 Microhardness as a function of distance from the sample's surface for the four tested variants (distance from surface on logarithmic scale)

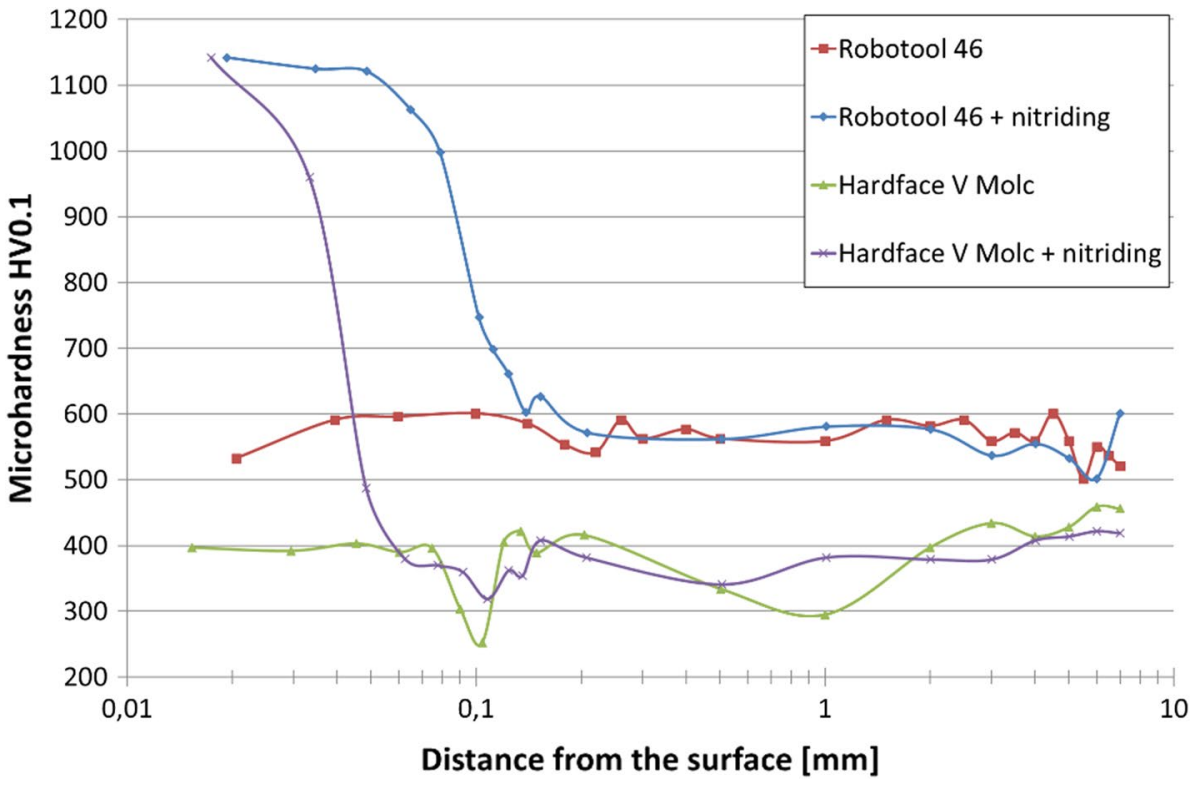

adopted criterion +50$)$. The nitrided layer is characterized by a hardness similar to that of layers obtained in nitriding processes of hot-work tool steels. In the case of the padding weld based on Hardface VMolc wire, nitrided in the same nitriding process, a layer of nitrides that was substantially shallower was observed, having a lower hardness than in the case of Robotool 46 material. This layer had an effective thickness of approx. $50 \mu \mathrm{m}$ (according to the adopted criterion +50 ). On this basis, lesser susceptibility to diffusion of nitrogen can be concluded in padding welds based on Hardface VMolc wire, which is due to its greater chromium and nickel content.
Samples prepared according to the description in Sect. 2 were tested in order to reveal internal stresses, present on the surface and in the surface layer, at depths of 50,100, and $150 \mu \mathrm{m}$. Test results are presented in Fig. 7.

The results presented in Fig. 7 confirmed the presence of stresses, particularly compressive stresses (with a negative value), in the surface layer. In the case of hybrid layers, these stresses were not only tested on the surface but also at depths of 50,100 , and $150 \mu \mathrm{m}$. Thanks to this, stresses caused by nitrogen diffusion into the surface layer were revealed. In the case of Robotool 46 material, where the nitrided layer reached an effective thickness of approx. $140 \mu \mathrm{m}$, very strong compressive stresses can be observed, reaching

\subsection{Results of X-ray diffraction internal stress tests}

Fig. 7 Distribution of internal stresses in surface layer

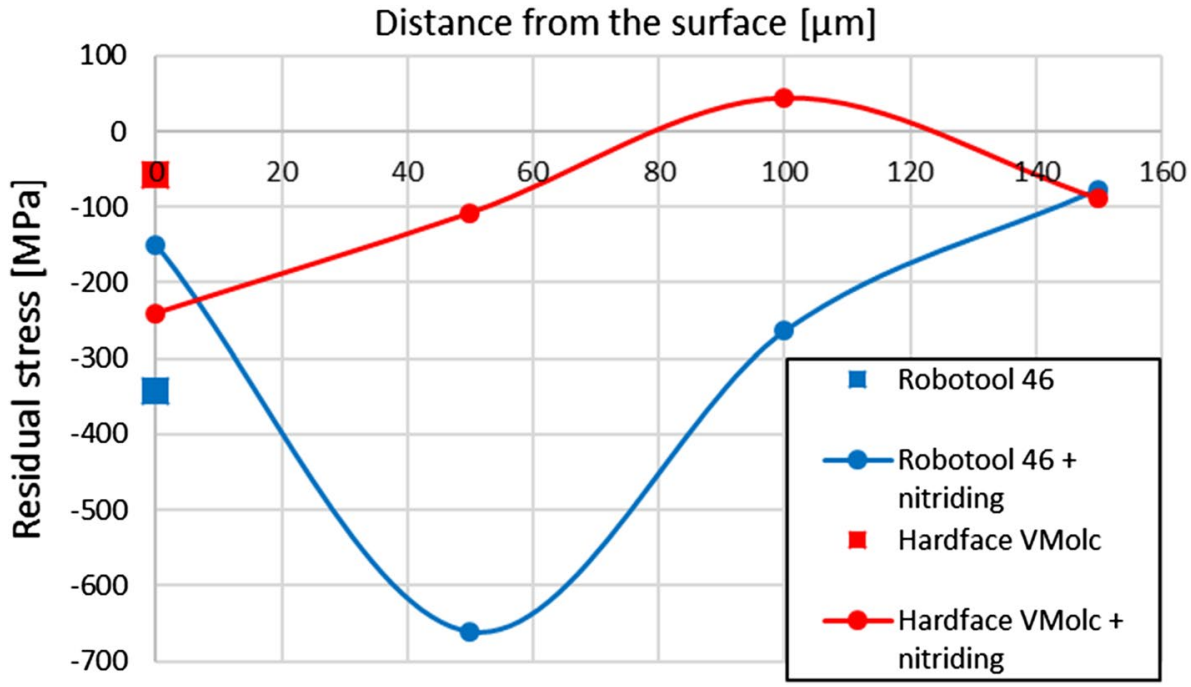


up to $650 \mathrm{MPa}$. Similarly, compressive stresses were also observed in the padding weld made with Hardface VMolc material; however, they had much smaller values. This is consistent with the microhardness measurement, which revealed that the layer's effective thickness was approx. $50 \mu \mathrm{m}$ and that this was due to impeded nitrogen diffusion in alloys of this type with high chromium content. In addition, it is worth noting that, besides introducing additional compressive stresses in the surface layer, nitriding during treatment relaxes welding stresses throughout the sample's entire volume. The previously conducted microstructural observations, in which the effect of diffusion transformations occurring in padding welds was observed during the nitriding process, may confirm this phenomenon.

\subsection{Results of wear tests}

Tribological wear tests were conducted according to the methodology described in Sect. 2. During measurement, the value of the friction coefficient was registered. Mean friction coefficient values, registered during the wear test, are given in Table 2. Comparative analysis showed that the lowest friction coefficient $(\mu=0.551)$ was obtained for the Robotool $46+$ nitriding sample, while the highest friction coefficient was registered for the sample hardfaced with Hardface VMolc, which was equal to $\mu=0.689$. High values of the friction coefficient indicate the occurrence of dry friction in the friction pair. In real forging processes, the lubrication is used which reduces the coefficient of friction.

Figure 8 presents a chart of registered friction coefficient values as a function of path.

Disturbances registered in the initial phase of the test are related to grinding in of friction pairs, where shearing of the peaks of roughness profiles, and the change in contact surface associated with it, occurs first, after which work of the friction pair is stabilized. It can be observed that, during the grinding-in period, the change of friction coefficient had a distinctly milder evolution for nitrided samples, where the evolution stabilized fastest, after just several meters of path, for the sample hardfaced with Hardface VMolc + nitriding, while in other cases, grinding-in periods were similar and amounted to approx. $75 \mathrm{~m}$ on average. Figure 8 also shows that, regardless of the hardfacing material, a decidedly lower

Table 2 Mean friction coefficient values

\begin{tabular}{lll}
\hline Sample name & $\begin{array}{l}\text { Mean friction coef- } \\
\text { ficient }\end{array}$ & SD \\
\hline Robotool 46 & 0.635 & 0.138 \\
Robotool 46 + nitriding & 0.551 & 0.112 \\
Hardface VMolc & 0.689 & 0.153 \\
Hardface VMolc + nitriding & 0.619 & 0.060 \\
\hline
\end{tabular}

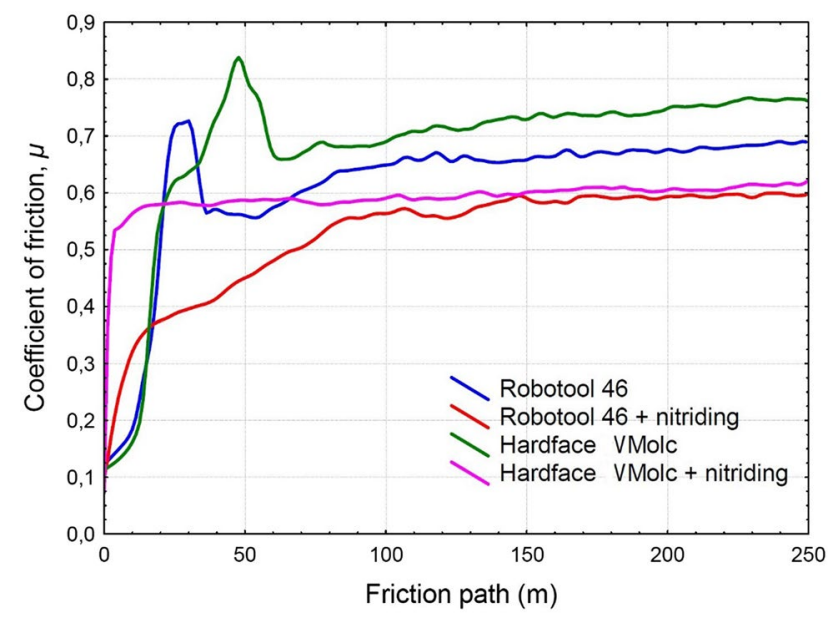

Fig. 8 Change of mean friction coefficient values (trend line) as a function of path

friction coefficient was registered throughout the entire duration of the test for nitrided samples.

The wear factor $[K]$, which was determined from Eq. (1), is a comparative measure of wear, accounting for key test parameters like load and friction path:

$K=\frac{\text { Volumetric loss }}{\text { Normal load } \times \text { sliding distance }}\left[\mathrm{mm}^{3} \mathrm{~N}^{-1} \mathrm{~m}^{-1}\right]$

Volumetric wear was determined as the product of the circumference of the circular wear trace formed in the ballon-disk test and the mean value of the sample's worn area. The area of the sample's wear profile was measured over the circumference at 14 points by means of a Dektak 150 contact profilometer, and example profiles are presented in Fig. 1. The values of determined factors are presented graphically in Fig. 9.

Determined wear factor values indicated that the sample with Robotool 46+ nitriding hardfacing exhibited the greatest resistance to wear. At the same time, the highest wear was determined for the sample with Hardface VMolc hardfacing. Similarly as in the case of the friction coefficient, based on wear factor values determined for the tested samples, it can be stated that nitriding decidedly improved resistance to friction wear.

Analysis of profiles (Fig. 10) and observations of obtained track surfaces showed that wear was adhesive in nature in the case of non-nitrided samples. In micro-areas of surface layer deformation, particularly at sites with the highest roughness peaks, local bonds of metallic friction surfaces formed and were then broken apart. The pits visible on worn surfaces (Fig. 11a, c) are characteristic of this type of mechanism, in effect of which the particles removed are, if not removed from the friction pair's contact area, subject 


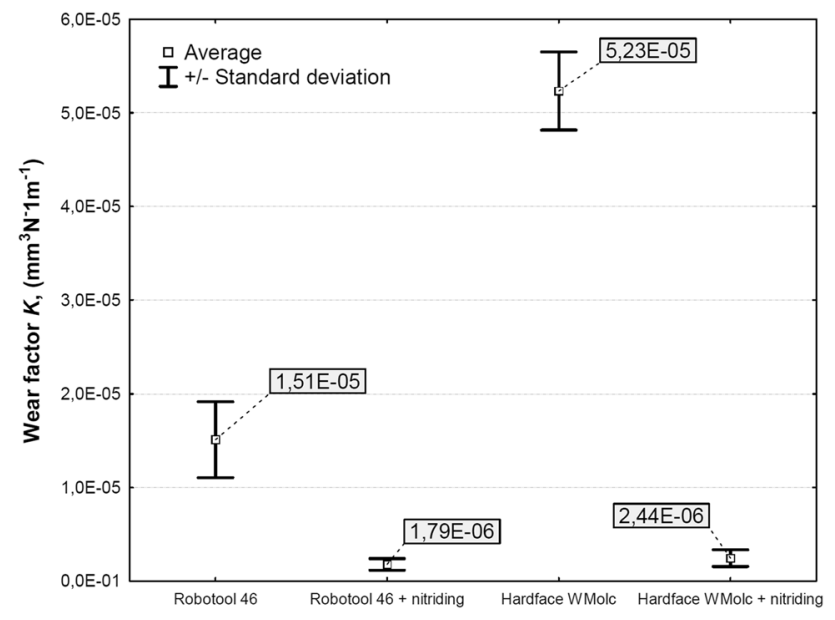

Fig. 9 Graphic representation of determined wear factor values

to plastic pressing into the valley of the wear track, which is particularly prominent in Fig. 11c. The analyzed tracks for non-nitrided samples have a depth of, accordingly, for the sample with Robotool 46 hardfacing $-8 \mu \mathrm{m}$, and for the sample with Hardface VMolc hardfacing-approx. $20 \mu \mathrm{m}$ (Fig. 10a, c). Tracks obtained for nitrided sample have a decidedly smaller depth, which is equal to, accordingly, for the sample with Robotool 46 hardfacing-approx. $1 \mu \mathrm{m}$, and for the sample with Hardface VMolc hardfacing - $2 \mu \mathrm{m}$ (Fig. 10b, d). Observations of track surfaces on nitrided samples demonstrated that abrasive wear is the dominant wear mechanism in both cases. This wear is intensified by hard particles, which are nitrided roughness peaks broken off in the initial phase of the test. As they are rolled within the area of the friction pair, these particles play the role of an abrasive, forming furrows on the sample surface typical of abrasive wear.

\section{Summary and conclusions}

Conducted tests made it possible to formulate the following observations and conclusions:
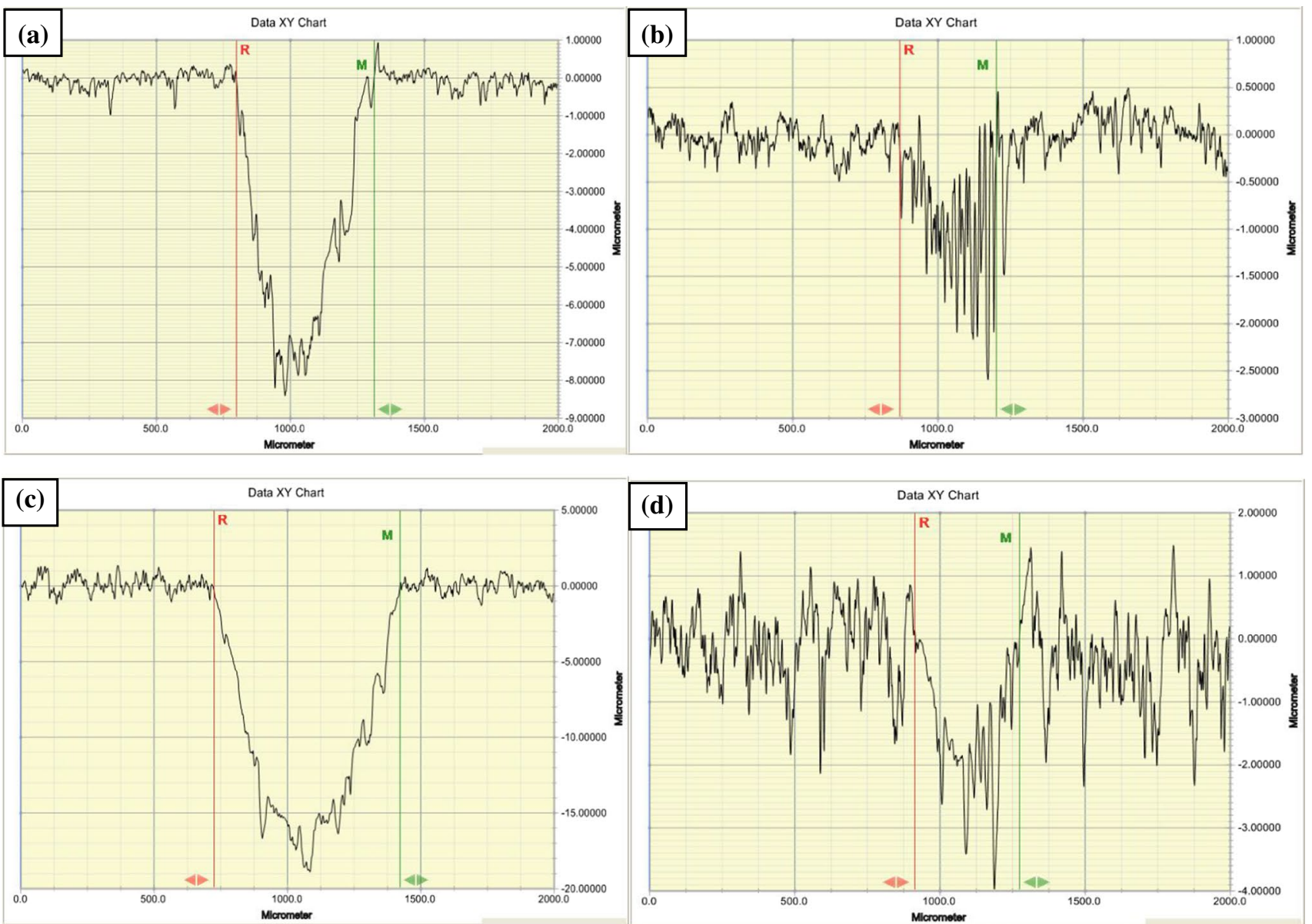

Fig. 10 Cross-sectional profile of wear path formed during test: a Robotool 46, b Robotool 46+ nitriding, c Hardface VMolc, d Hardface VMolc + nitriding 
(a)
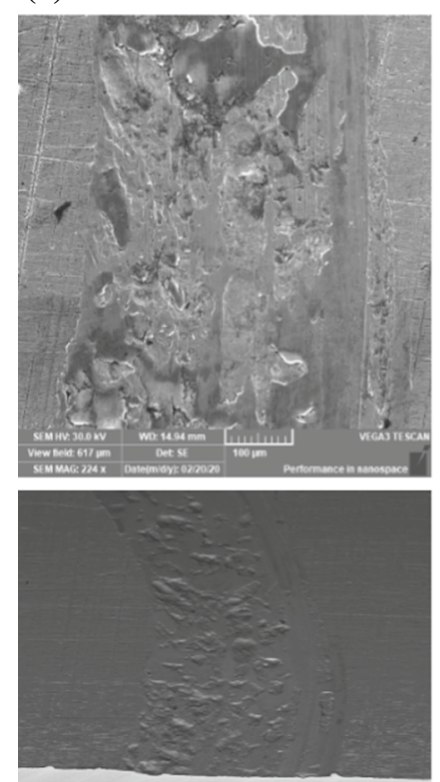

(b)
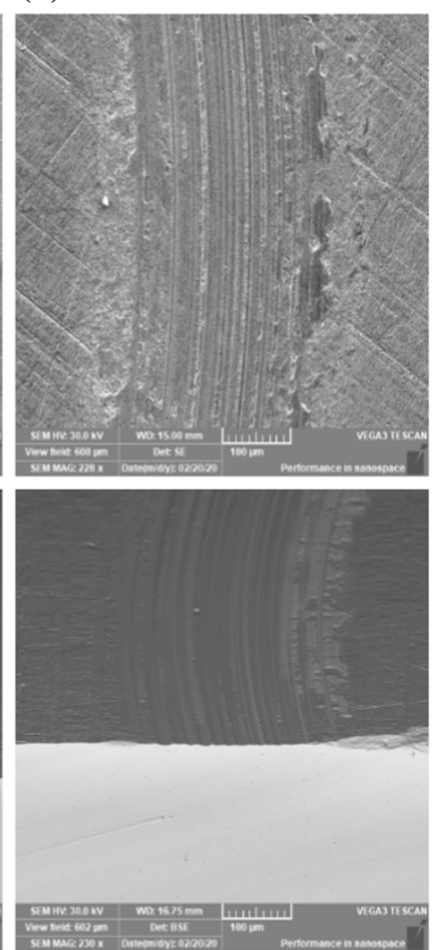

(c)

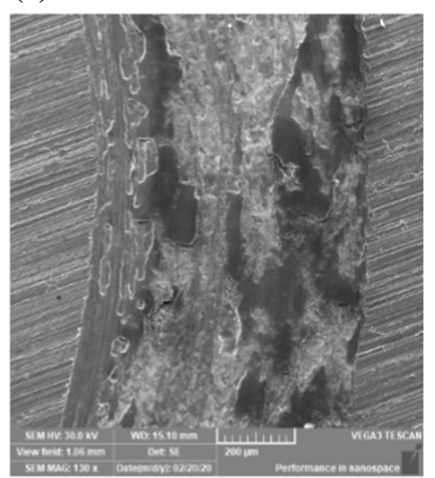

(d)

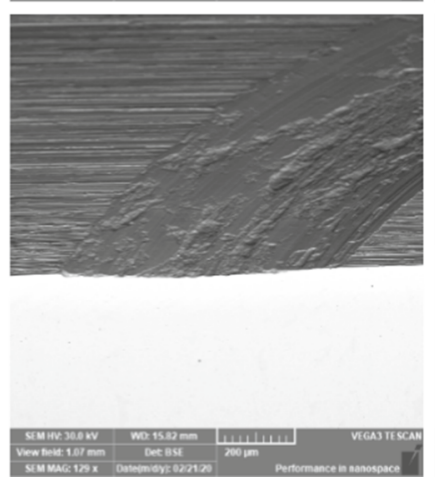

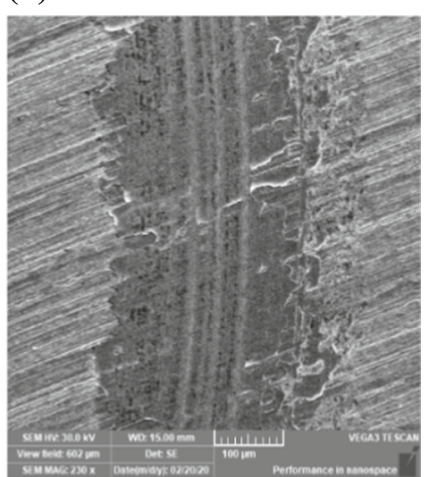

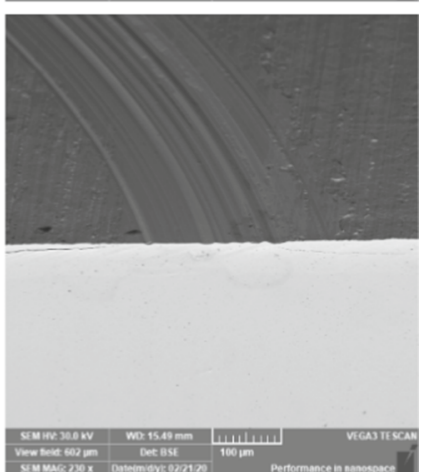

Fig. 11 View of path worn during test from the top (top) and in cross section (bottom): a Robotool 46, b Robotool 46 + nitriding, c Hardface VMolc, d Hardface VMolc + nitriding

1. The applied FCAW-S technique of hardfacing with selfshielded powder wires is characterized by high precision of laying beads (passes) of the layer and by high efficiency of the hardfacing process and can successfully replace hardfacing of forging dies by means of fluxcovered electrodes. Padding welds with a thickness of approx. 7-8 $\mathrm{mm}$ can be laid down in three layers.

2. According to the IIW classification [25], the Robotool 46 welding metal has a high-alloy martensitic structure with composite $\mathrm{Fe}, \mathrm{Cr}, \mathrm{Mo}, \mathrm{V}$ carbides, with a hardness of 45-60 HRC depending on the heat treatment of padding welds. Padding welds obtained from this wire have the properties of hot-work tool steel, similar to those of steel grade $\mathrm{H} 11$.

3. The Hardface VMolc welding metal has a ferritic-bainitic structure with lower hardness compared to H11 material, similar to that of L6 steel used for manufacturing of hammer forging dies. Also, in this case, it is beneficial to apply nitriding treatment in order to achieve better operational properties.

4. Tests covered samples in states after hardfacing and after thermochemical treatment-nitriding. The thickness of the nitrided padding weld made of Robotool 46 is approx. $0.14 \mathrm{~mm}$, and made of Hardface VMolc wire, approx. $0.05 \mathrm{~mm}$. The heat of nitriding treatment had a favorable influence on the process of fine-dispersive carbide precipitation inside grains of the structure of padding weld layers and in the HAZ.

5. Measurement of internal stresses by X-ray diffraction revealed the presence of compressive (negative) stresses, which occur in the surface layer as a result of the nitriding process. Their presence is desirable, as they result in greater resistance to propagation of fatigue cracks in the surface layer.

6. Tribological tests demonstrated that nitriding of padding welds distinctly increases their resistance to abrasive wear. The hybrid layers were characterized by lesser wear, which took on the form of abrasive wear through furrowing. Hardfaced layers were worn significantly more intensively, and observation of the abrasive track revealed traces of adhesive wear.

Based on the obtained results, it can be stated that nitriding contributes to increasing the durability of hardfaced or rebuilded layers by pad welding, because, during nitriding, the padding weld is subject to soaking, and the process of fine-dispersive carbide precipitation occurs inside grains. Thus, beneficial compressive stresses are introduced into the surface layer, the surface and surface layer are hardened, and thanks to this, resistance to abrasive wear increases. It is 
recommended to nitride hardfaced layers currently applied, under the condition that the padding weld material is susceptible to nitrogen diffusion. It may also prove beneficial to replace ordinary tool steels improved by nitriding with hybrid layers, combining preventive hardfacing and nitriding treatment.

Funding This study was funded by the National Science Centre in Poland (NCN) [Grants Nos. 2017/25/N/ST8/02792 and 2018/28/T/ ST8/00491].

\section{Compliance with ethical standards}

Conflict of interest All authors declare that they have no conflict of interest.

Open Access This article is licensed under a Creative Commons Attribution 4.0 International License, which permits use, sharing, adaptation, distribution and reproduction in any medium or format, as long as you give appropriate credit to the original author(s) and the source, provide a link to the Creative Commons licence, and indicate if changes were made. The images or other third party material in this article are included in the article's Creative Commons licence, unless indicated otherwise in a credit line to the material. If material is not included in the article's Creative Commons licence and your intended use is not permitted by statutory regulation or exceeds the permitted use, you will need to obtain permission directly from the copyright holder. To view a copy of this licence, visit http://creativecommons.org/licenses/by/4.0/.

\section{References}

1. Deshpande M, Altan T. Selection of die materials and surface treatments for increasing die life in hot and warm forging. https ://www.forging.org/uploaded/content/media/Altan_paper_Die_ materials_and_surface_treatments6.pdf.

2. Gronostajski Z, Pater Z, Madej L, et al. Recent development trends in metal forming. Arch Civ Mech Eng. 2019;19(3):898-941.

3. Widomski P, Gronostajski Z. Comprehensive review of methods for increasing the durability of hot forging tools. Proc Manuf. 2020. https://doi.org/10.1016/j.promfg.2020.04.280.

4. Lange K, Cser L, Geiger M, Kals JAG. Tool life and tool quality in bulk metal forming. CIRP Ann Manuf Technol. 1992;41(2):667-75.

5. Hawryluk M. Review of selected methods of increasing the life of forging tools in hot die forging processes. Arch Civ Mech Eng. 2016;16(4):845-66.

6. Hawryluk M, Gronostajki Z, Kaszuba M, Polak S, Widomski P, Ziemba J. Analysis of the wear of forging tools surface layer after hybrid surface treatment. Int J Mach Tools Manuf. 2017. https:// doi.org/10.1016/j.ijmachtools.2016.12.010.

7. Yilkiran T, Behrens BA, Paschke H, Weber M, Brand H. The potential of plasma deposition techniques in the application field of forging processes. Arch Civ Mech Eng. 2012;12(3):284-91.

8. Jia Z, Ji J. Influence analysis of shot peening on hot forging die. Int J Adv Manuf Technol. 2017;90(5-8):1779-87.

9. Gronostajski Z, Kaszuba M, Widomski P, Smolik J, Ziemba J, Hawryluk M. Analysis of wear mechanisms of hot forging tools protected with hybrid layers performed by nitriding and PVD coatings deposition. Wear. 2019;420-421:269-80.

10. Gronostajski Z, Widomski P, Kaszuba M, Zwierzchowski M, Hawryluk $M$. Influence of both hardfaced and nitrided layers on the durability of hot forging tools. Surf Innov. 2018;6(4-5):301-10.

11. Mittemeijer EJ. Fundamentals of nitriding and nitrocarburizing. In: Dossett JL, Totten GE, editors. Steel heat treating fundamentals and processes. Washington: ASM; 2018.

12. Kucharska B, Michalski J, Wójcik G. Mechanical and microstructural aspects of $\mathrm{C} 20$-steel blades subjected to gas nitriding. Arch Civ Mech Eng. 2019. https://doi.org/10.1016/j.acme.2018.09.006.

13. Mrzygłód B, Hawryluk M, Gronostajski Z, et al. Durability analysis of forging tools after different variants of surface treatment using a decision-support system based on artificial neural networks. Arch Civ Mech Eng. 2018;18(4):1079-91.

14. Kashani H, Amadeh A, Farhani M. Improvement of wear resistance of hot working tool steel by hardfacing. Part 1 -effect of microstructure and hardness. Mater Sci Technol. 2007. https:// doi.org/10.1179/174328407X154220.

15. Kashani H, Amadeh A, Vatanara MR. Improvement of wear resistance of hot working tool steel by hardfacing. Part 2-case study. Mater Sci Technol. 2008;24(3):356-60.

16. Behrens BA, Yilkiran T, Ocylok S, Weisheit A, Kelbassa I. Deposition welding of hot forging dies using nanoparticle reinforced weld metal. Prod Eng. 2014;8:645-58.

17. Jeyaprakash N, Yang CH, Duraiselvam M, Sivasankaran S. Comparative study of laser melting and pre-placed $\mathrm{Ni}-20 \% \mathrm{Cr}$ alloying over nodular iron surface. Arch Civ Mech Eng. 2020. https://doi. org/10.1007/s43452-020-00030-4.

18. Buchmayr B. Damage, lifetime, and repair of forging dies. BHM Berg Huettenmaenn Monatsh. 2017;162:88-93.

19. Ahn DG, Lee HJ, Cho JR, Guk DS. Improvement of the wear resistance of hot forging dies using a locally selective deposition technology with transition layers. CIRP Ann Manuf Technol. 2016;65(1):257-60.

20. Duchek M, Koukolikova M, Kotous J, Majer M. Increasing of the lifetime of large forging dies by repairwelding. In: IOP conference series: materials science and engineering; 2018.

21. Alphonsa J, Padsala BA, Chauhan BJ, et al. Plasma nitriding on welded joints of AISI 304 stainless steel. Surf Coatings Technol. 2013. https://doi.org/10.1016/j.surfcoat.2012.05.113.

22. Lukin VI, Kovalchuk VG, Golev YV, Mazalov IS. Ovchenkova II (2013) Welding a creep-resisting Ni-Co-Cr (VZh171) alloy strengthened by nitriding. Weld Int. 2013. https://doi. org/10.1080/09507116.2013.796642.

23. Gronostajski Z, Widomski P, Kaszuba M, et al. Influence of the phase structure of nitrides and properties of nitrided layers on the durability of tools applied in hot forging processes. J Manuf Process. 2020;52:247-62.

24. Tasak E, Ziewiec A, Ziewiec K. Problemy wystepujące przy spawaniu i naprawie spoin stali różnorodnych. Arch Foundry/ Arch Odlew. 2006;6(21):221-7.

25. International Institute of Welding. Document II-421-03. A Classification system for hardfacing alloys.

Publisher's Note Springer Nature remains neutral with regard to jurisdictional claims in published maps and institutional affiliations. 